\title{
Karakteristik dan Persepsi Wisatawan Mancanegara di Kawasan Sanur dan Canggu, Bali
}

\author{
Komang Ratih Tunjungsari \\ Program Studi D4 Manajemen Perhotelan dan Program Studi D3 Perhotelan, Sekolah \\ Tinggi Pariwisata Bali Internasional \\ ratih.tunjung@stpbi.ac.id
}

\begin{abstract}
Kegiatan pariwisata di Bali sudah dimulai sejak awal tahun 1920-an dan kemudian pariwisata akhirnya dijadikan salah satu solusi untuk memperbaiki kondisi keuangan setelah kemerdekaan. Diawali pada pembukaan bandara internasional Ngurah Rai di Bali, tahun 1974 pemerintah mencanangkan formula kepariwisataan di Bali yang berbasis pariwisata budaya. Kegiatan pariwisata yang dilaksanakan oleh wisatawan mancanegara ketika itu sebagian besar menikmati suguhan budaya dari masyarakat lokal, seperti tari-tarian, pembuatan patung, keindahan alam yang asri, serta kehidupan masyarakat lokal. Perkembangan kegiatan pariwisata di Bali tidak dapat dihindari seiring dengan majunya teknologi. Memasuki tahun 2000-an, kegiatan wisatawan mancanegara pun berubah, begitu pula juga karakteristik dari wisatawan tersebut dengan semakin cepatnya perkembangan informasi yang ada. Adapun tujuan dari penelitian ini adalah untuk mengetahui dan menganalisis karakteristik wisatawan mancanegara yang mengunjungi daerah pantai di Bali, khususnya di kawasan pantai Sanur dan kawasan Canggu. Metode yang digunakan adalah dengan menyebarkan kuesioner kepada wisatawan yang ada di kawasan pantai tersebut dengan menggunakan random purposive sampling kepada wisatawan mancanegara. Metode analisis yang digunakan adalah menggunakan deskriptif kualitatif untuk memaparkan hasil penelitian yang didapatkan. Menggunakan analisis sederhana didapatkan bahwa sebagian wisatawan masih berada dalam usia produktif 18-35 tahun dan yang unik adalah masih banyak wisatawan yang tinggal di daerah tersebut baru pertama kali mengunjungi Bali. Kedua kawasan pantai tersebut memiliki karakteristik yang berbeda karena kawasan Sanur memang merupakan kawasan pariwisata sejak awal sejarah pariwisata di Bali, sedangkan kawasan Canggu merupakan kawasan pariwisata yang baru sejak tahun 2000-an dikenal wisatawan. Sehingga terdapat perbedaan hasil di beberapa karakteristik, seperti asal negara dan tipe akomodasi tempat tinggal wisatawan tersebut. Menariknya, transportasi menggunakan sepeda motor menjadi pilihan bagi sebagian besar wisatawan di kawasan wisata tersebut. Persepsi wisatawan tentang Bali sudah baik dengan budaya dan wisatanya, akan tetapi menyayangkan pengelolaan masalah sampah dan kemacetan di Bali yang masih belum tertata.
\end{abstract}

Keywords: Karakterisitik, aktivitas, persepsi, wisatawan mancanegara, Bali 


\section{PENDAHULUAN}

Perkembangan industri pariwisata di Bali sudah dibangun di Bali sebelum tahun 1972 oleh pemerintah Indonesia. Namun ketika sebelum kemerdekaan Indonesia dan selama penjajahan Belanda, pembangunan pariwisata di Bali telah berjalan karena 'dikonstruksi' oleh pihak asing terutama Belanda. Industri pariwisata di Bali dikembangkan karena sebagai salah satu cara bagi pemerintah Belanda untuk menghapuskan luka ketika terjadi perang puputan - perang habishabisan sampai akhir hayat para pejuang Bali, yang pada akhirnya berakhir pada penjajahan oleh Belanda pada tahun 1908 (Malbos, 2010). Perkembangan bisnis pariwisata di Bali pada saat itu didominasi oleh orang-orang Eropa. Pada saat itu, mereka yang memiliki modal untuk membangun hotel, toko souvenir - yang dibangun di Sanur sebagai tempat distribusi bagi lukisan dan ukiran. Toko souvenir tersebut dikelola oleh dua orang Jerman bersaudara, Hans dan Rolf Neuhaus, yang pergi meninggalkan Jerman pada tahun 1920an untuk pergi mengelilingi dunia dan memulai usaha mereka tersebut pada tahun 1935 di daerah Sanur (Vickers, 2012).

Perkembangan wisatawan pada saat itu berkembang dan meningkat pada tahun 1930. Sekitar 100 orang wisatawan mengunjungi Bali setiap bulannya. Pada dekade berikutnya, tahun 1940, jumlah wisatawan meningkat dengan cukup pesar hingga 250 orang wisatawan per bulan. Kegiatan pariwisata pada saat itu mencakup paket wisata 5 hari. Sesampainya di Buleleng, akan diantar menuju Denpasar. Setelah tiba di Denpasar, wisatawan kemudian akan disuguhi tarian tradisional Bali. Orang lokal juga akan sangat senang melihat kedatangan wisatawan asing dari Sanur atau Denpasar Timur. Tidak ada interaksi yang signifikan antara wisatawan dengan masyarakat lokal, kecuali jika mereka ikut mengantarkan wisatawan berpindah (Vickers, 2012).

Setelah kemerdekaan Indonesia kebijakan pariwisata di Bali kemudian diatur oleh pemerintah Indonesia bekerjasama dengan pemerintah daerah dengan tujuan dapat memberikan kontribusi bagi masyarakat local. Pemerintah pada saat itu berusaha untuk mendapatkan tema yang cocok untuk pembangunan pariwisata Bali. Pada akhirnya dipilihlah pariwisata kebudayaan sebagai basis pengembangan pariwisata yang ada di Bali pada tahun 1971 (Picard, 2006). Rancangan utama pengembangan Bali didesain pada tahu 1971 oleh pemerintah Bali dan konsultan Perancis, bernama Société Centrale pour l'outre-Mer Touristique equipment (SCETO). Rekomendasi dari SCETO pada saat itu adalah menyediakan beberapa wilayah yang akan dikembangkan sebagai daerah pariwisata di Bali, seperti Nusa Dua, Sanur dan Lovina. Daerah yang di luar daerah pesisir pantai tersebut akan dilestarikan sebagai daerah yang lebih mahal dan harus dikontrol dengan baik untuk menjaga karakter masyarakat local Bali untuk menghindari kesenjangan yang ditimbulkan dari kebijakan pariwisata tersebut (Gregorius, 2008). 
Tabel. 1.1 Kedatangan Wisatawan ke Indonesia dan ke Bali tahun 1965 1973

\begin{tabular}{|l|l|l|}
\hline Tahun & $\begin{array}{l}\text { Direktorat } \\
\text { Jenderal } \\
\text { Pariwisata } \\
\text { (Indonesia) }\end{array}$ & $\begin{array}{l}\text { Wisatawan } \\
\text { asing di Bali }\end{array}$ \\
\hline 1964 & 35,915 & \\
\hline 1965 & $29,367(-18.25 \%)$ & \\
\hline 1966 & $19,311(-34.25 \%)$ & $\begin{array}{l}2,150 \\
\text { (perkiraan) }\end{array}$ \\
\hline 1967 & 33,234 & \\
\hline 1968 & 52,000 & 5,767 \\
\hline 1969 & 75,000 & 10,976 \\
\hline 1970 & & 23,110 \\
\hline 1971 & $\begin{array}{l}160,816 \\
\text { (perkiraan) }\end{array}$ & 33,033 \\
\hline 1972 & & 47,360 \\
\hline 1973 & & 53,775 \\
\hline
\end{tabular}

Sumber: Francillon, 1979.

Pada tabel di atas telah disampaikan mengenai jumlah kedatangan wisatawan di Bali yang berhasil dihimpun oleh Universitas Udayana dan UNESCO dari tahun 1965-1973. Dalam tabel tersebut dikatakan bahwa pada tahun 1964, jumlah wisatawan asing ke Indonesia masih tergolong relatif cukup besar dibandingkan dengan tahun berikutnya pada tahun 1965, dikarenakan situasi kondisi nasional pada saat itu sedang chaos akibat isu kudeta pada tahun tersebut. Pada tahun berikutnya tahun 1967, maka jumlah wisatawan asing ke Indonesia mulai membaik.

Perkembangan pariwisata yang membaik dapat kita lihat dalam datadata yang tiap tahun menunjukkan peningkatan jumlah wisatawan yang berkunjung ke Bali. seperti data yang ditunjukkan pada tabel 1.2 dibawah, bahwa wisatawan asing yang menduduki peringkat pertama sejak tahun 2007 hingga tahun 2011 adalah Asutralia, walaupun secara total dimenangkan oleh Asia Pasifik karena terdapat Cina yang juga memberikan kontribusi wisatawan yang begitu besar pada era saat ini.

Table 1.2 Kedatangan Langsung Wisatawan Asing ke Bali tahun 2007

$-2011$

\begin{tabular}{|c|c|c|c|c|c|c|}
\hline $\begin{array}{l}\mathrm{N} \\
\mathrm{o}\end{array}$ & $\begin{array}{c}\text { KEBANGSA } \\
\text { AN }\end{array}$ & 2007 & 2008 & 2009 & 2010 & 2011 \\
\hline 1 & $\begin{array}{l}\text { ASIA } \\
\text { PASIFIK }\end{array}$ & 754,777 & $\begin{array}{l}800,98 \\
4 \\
\end{array}$ & 819,654 & 772,716 & 785,065 \\
\hline 2 & AUSTRALIA & 204,421 & 308,698 & 446,042 & 647,872 & 790,965 \\
\hline 3 & $\begin{array}{l}\text { SELANDIA } \\
\text { BARU }\end{array}$ & 14,107 & 16,346 & 23,707 & 31,377 & 37,015 \\
\hline 4 & ASEAN & 168,103 & 205,694 & 224,941 & 294,421 & 337,161 \\
\hline 5 & AFRIKA & 9,988 & 11,441 & 11,324 & 12,973 & 148,565 \\
\hline 6 & AMERIKA & 83,717 & 99,848 & 109,728 & 113,094 & 139 \\
\hline 7 & EROPA & 427,686 & 523,223 & 590,047 & 613,774 & 644,156 \\
\hline 8 & $\begin{array}{l}\text { TIMUR } \\
\text { TENGAH }\end{array}$ & 2,055 & 2,658 & 4,502 & 6,600 & 7,534 \\
\hline 9 & LAIN-LAIN & 0 & 0 & 0 & 231 & 367 \\
\hline & TOTAL & $\begin{array}{l}1,664,85 \\
4\end{array}$ & $\begin{array}{l}1,968,89 \\
2\end{array}$ & $\begin{array}{l}2,229,9 \\
45\end{array}$ & $\begin{array}{l}2,493,0 \\
58\end{array}$ & $\begin{array}{l}2,750,96 \\
7\end{array}$ \\
\hline
\end{tabular}

Sumber : Pemerintah Kota Denpasar, 2012.

Jumlah wisatawan yang datang ke Bali sejak masa tersebut semakin meningkat hingga pada tahun-tahun berikutnya. Karakteristik wisatawan maupun demografis wisatawan yang datang ke Bali pun semakin hari semakin mengalami perubahan. Banyak factor yang menyebabkan hal ini terjadi salah satunya adalah kemajuan teknologi yang membuat biaya perjalanan menjadi lebih murah dan informasi lebih mudah didapat. Sesuai dengan peningkatan aktivitas terutama di industry pariwisata yang mendatangkan 7,5 Trilliun Juta Dollar AS atau sekitar 9,8 persen dari Produk Domestik Bruto (PDB) dunia di tahun 2014.

Laporan dari World Tourism and Travel Council juga memprediksi bahwa industry pariwisata akan terus meningkat aktivitasnya bahkan mencapai sekitar 11,3 Trilyun juta dollar AS atau sekitar 10,5 persen dari 
total PDB dunia serta memberikan 357 juta pekerjaan sampai dengan tahun 2025 (WTTC, 2015). Hal tersebut sangat mendukung peningkatan kunjungan wisatawan asing ke Indonesia dan Bali pada tahun 2016 hanya mencapai 11.519.275 dan pada tahun 2017 meningkat ke angka 14.039.799 wisatawan asing dengan total pertumbuhan tingkat wisatawan adalah 21,88 persen. Sedangkan jumlah wisatawan asing yang ke Bali pada tahun 2016 sebanyak 4.927.937 dan pada tahun 2017 mencapai 5.697.739 yang artinya mengalami peningkatan sebesar 15,62 persen pada tahun tersebut (Badan Pusat Statistik, 2018).

Di awal perkembangan wisata di Bali pada tahun 1930-an, wisatawan yang datang sebagian besar berasal dari daratan Eropa maupun Amerika. Akan tetapi sekarang asal wisatawan sudah beragam jika dilihat dari tabel wisatawan di atas. Seperti yang disebutkan di atas, daerah wisatawan yang berkembang sejak dulu adalah Sanur dan kawasan Bali Selatan seperti Nusa Dua dan daerah Gianyar. Hal tersebut dapat dipahami dari literature-literatur perkembangan pariwisata yang menunjukkan aktivitas wisatawan sebagian besar berada di wilayah tersebut. Seperti yang dikatakan oleh Indrawarti (2010), bahwa usia wisatawan yang berkunjung ke Sanur beragam dan sebagian besar berusia lanjut dan berasal dari kawasan Eropa seperti Inggris, Jerman, dan Belanda. Sebagian besar wisatawan tersebut datang karena sangat menyukai budaya dan tradisi masyarakat setempat serta memiliki kenangan tersendiri terhadap Sanur.
Sedangkan Canggu merupakan suatu daerah wisata yang pada saat pengembangan pariwisata di Bali belum berkembang sebagai daerah wisata.

Seperti yang disebutkan pada Bank Dunia (2003), bahwa kegiatan pembangunan pariwisata di Bali pada awal tahun 1950-an di daerah Nusa Dua Selatan, Sanur, Kuta dan Legian. Canggu pada saat dahulu sebagian besar bentuk lahannya adalah persawahan dan hingga saat ini, masih terlihat di sudut-sudut daerah di Canggu masih relative cukup banyak areal persawahan di tengahtengah pembangunan sarana penunjang kegiatan pariwisata. Sehingga adapun tujuan dari penulisan ini adalah untuk mengetahui bagaimana karakteristik serta persepsi wisatawan di kedua daerah wisata yang berbeda di Bali. Peneliti ingin lebih melihat perbedaan kegiatan ataupun perbedaan sebaran demografis dari wisatawan mancanegara yang mengunjungi kedua area tersebut. Selain itu, tidak hanya demografis, namun juga karakteristik dari kegiatan pariwisata yang diminati oleh wisatawan di kedua tempat tersebut. Tidak hanya hal ini, penulis juga ingin mengetahui sedikit tentang persepsi wisatawan mengenai kawasan Sanur dan Canggu sebagai citra pariwisata Bali. Manfaat dari penelitian ini adalah untuk dapat memberikan saran terhadap kebijakan-kebijakan pariwisata di Bali agar tatanan pengembangan maupun pembangunan pariwisata di Bali lebih matang. 


\section{TINJAUAN PUSTAKA}

\section{Karakteristik Wisatawan}

Sebelum mengetahui mengenai terminologi karakteristik wisatawan, penulis menjabarkan beberapa definisi wisatawan yang dikutip dari beberapa ahli. Wisatawan merupakan orang yang melakukan kegiatan wisata ke suatu tempat dengan tujuan berwisata dan tidak dengan tujuan mencari uang atau bekerja. Objek wisata yang dipilih oleh wisatawan juga akan beragam, tergantung pada motivasi wisatawan tersebut untuk mengunjungi suatu destinasi wisatawan yang berhubungan sangat erat dengan kegiatan wisata yang akan dipilih oleh wisatawan tersebut. Menurut G.A Schmoll, wisatawan merupakan individu atau kelompok individu yang merencanakan kemampuan daya beli yang dimilikinya untuk melakukan perjalanan dengan tujuan rekreasi dan liburan. Berdasarkan wilayah dan ruang lingkup perjalanannya, wisatawan dibagi menjadi wisatawan asing dan wisatawan dalam negeri atau wisatawan domestik atau wisatawan nusantara untuk istilah Bahasa Indonesia. Wisatawan asing adalah wisatawan yang tinggal di suatu negara dan bepergian ke negara lain, bukan tempat tinggalnya untuk melakukan perjalanan. Sedangkan wisatawan domestik adalah wisatawan yang bepergian di daerah atau negara tempatnya. Wisatawan transit adalah wisatawan yang melakukan perjalanan ke suatu negara asing, yang bukan merupakan kehendaknya, karena keterpaksaan harus mampir ke negara asing tersebut sebagai penghubung ke negara asing tujuannya. Selain itu wisatawan bisnis adalah orang asing yang melakukan perjalanan dengan tujuan mendapatkan tugas, atau pekerjaan. Setelah pekerjaannya selesai, maka wisatawan bisnis tersebut dapat melakukan aktivitas liburan di negara asing tujuannya.

Karakteristik wisatawan yang lain dibedakan berdasarkan konsep perjalanan wisatawan tersebut atau motivasi maupun kegiatannya. Karakteristik wisatawan tersebut dibagi menjadi trip descriptor dan tourist descriptor. Karakteristik berdasarkan trip descriptor dibedakan menjadi lebih spesifik berdasarkan tujuan dari perjalanan tersebut, yakni mengunjungi teman atau keluarga (visiting friends and relatives), perjalanan rekreasi, berdasarkan lama perjalanan, berdasarkan cara perjalanan, berdasarkan informasi perjalanan, berdasarkan jenis akomodasi yang digunakan, berdasarkan alat transportasi yang digunakan untuk perjalanan, pengorganisasian perjalanan serta besarnya pengeluaran untuk berwisata (Seaton and Bennet, 1996). Karakteristik wisatawan berdasarkan trip descriptor digunakan pada penelitian ini seperti yang terlihat pada hasil pembahasan di bawah ini.

Tourist descriptor merupakan pembagian karakteristik wisatawan berdasarkan karakter sosiodemografis, sosio psikografis, dan geografis. Seperti yang dijelaskan oleh Spillane dalam Fandeli (2000), karakteristik sosio demografis merupakan karakteristik yang relatif sering muncul dan mendasar pada penelitian pariwisata, karena 
berhubungan dengan perencanaan dan pemasaran. Beberapa poin yang digunakan dalam penelitian karakteristik sosio demografis adalah jenis kelamin, umur, anggota keluarga, tingkat pendidikan, status perkawinan, dan ukuran keluarga. Karakteristik wisatawan yang mencakup karakteristik psikografis adalah kelas sosial, life style, dan karakteristik personal dari wisatawan itu sendiri dalam memutuskan kunjungan ke suatu objek wisata maupun ke suatu negara. Karakteristik geografis merupakan pembagian wisatawan berdasarkan daerah atau lokasi asalnya, bisa berdasarkan negara asal, kota asalanya, desa, provinsi. Ataupun kemudian dapat dianalisi dari relatifitas besarnya ukuran kota tempat tinggal serta kepadatan penduduk di negara, kota maupun desa asalnya tersebut.

\section{Persepsi Wisatawan}

Persepsi tidak terjadi begitu saja, tetapi melalui suatu proses, Walgito (1989:54) menyatakan bahwa terbentuknya persepsi melalui suatu proses, dimana secara langsung proses persepsi dapat dikemukakan sebagai berikut: berawal dari objek yang menimbulkan rangsangan dan rangsangan tersebut mengenai alat indra atau reseptor. Proses ini dinamakan proses kealaman (fisik), kemudian rangsangan yang diterima oleh alat indra dilanjutkan oleh syaraf senisoris ke otak. Proses ini dinamakan proses fisiologis, selanjutnya terjadilah suatu proses di otak, sehingga individu dapat menyadari apa yang ia terima dengan reseptro itu, sebagai suatu rangsangan yang diterimanya. Proses yang terjadi dalam otak/pusat kesadaran itulah dinamakan dengan proses psikologis, dengan demikian taraf terakhir dari proses persepsi ialah individu menyadari tentang apa yang diterima melalui alat indra (reseptor). Hal tersebut juga dikatakan oleh Sugihartono, dkk (2007: 8), bahwa persepsi adalah kemampuan otak dalam menerjemahkan stimulus atau proses untuk menerjemahkan stimulus yang masuk ke dalam alat indera manusia. Waidi (2006: 118) juga mengatakan bahwa persepsi merupakan hasil kerja otak dalam memahami atau menilai suatu hal yang terjadi di sekitarnya.

Persepsi merupakan suatu proses yang didahului oleh proses penginderaan, yaitu merupakan proses diterimanya stimulus atau rangsangan oleh individu melalui alat indera atau juga disebut proses sensoris. Namun proses itu tidak berhenti begitu saja, melainkan stimulus tersebut diteruskan dan proses selanjutnya merupakan proses persepsi. Proses persepsi tidak dapat lepas dari proses penginderaan, karena merupakan proses pendahulu (Walgito, 2010:99). Proses penginderaan akan berlangsung setiap saat, pada waktu individu menerima stimulus melalui alat indera, seperti mata sebagai penglihatan, telinga sebagai alat dengar, hidung sebagai alat pembauan, lidah sebagai alat pengecapan, kulit pada telapak tangan sebagai alat perabaan. Definisi mengenai persepsi juga diungkapkan oleh Rivai (2002), sebagai proses yang ditempuh individu utnuk mengorganisasikan dan menafsirkan kesan-kesan indera 
mereka agar memberikan makna bagi lingkungan mereka. Persepsi penting dalam studi perilaku organisasi, karena persepsi memberikan makna bagi lingkungan.

\section{Syarat Terjadinya Persepsi}

Menurut Sunaryo (2004:98), dalam terjadinya suatu persepsi harus terdapat unsur-unsur berikut dibawah ini :

1. Adanya objek yang dipersepsi

2. Adanya perhatian yang merupakan langkah pertama sebagai persiapan dalam mengadakan persepsi.

3. Adanya alat indera/reseptor yaitu alat untuk menerima stimulus.

4. Saraf sensoris sebagai alat untuk meneruskan stimulus ke otak, kemudian sebagai alat untuk mengadakan respon.

\section{Faktor-faktor yang berperan dalam persepsi}

Menurut Walgito (2004), faktorfaktor yang berperan dalam persepsi dapat dikemukakan adanya beberapa faktor, yaitu:

1. Objek yang dipersepsi

Objek menimbulkan stimulus yang mengenai alat indera atau reseptor. Stimulus dapat datang dari luar diri individu yang mempersepsi, tetapi juga dapat datang dari dalam diri individu yang bersangkutan secara langsung mengenai syaraf penerima yang bekerja sebagai reseptor. Namun sebagian terbesar stimulus datang dari luar individu.

2. Alat indera, syaraf, dan pusat susunan syaraf

Alat indera atau reseptor merupakan alat untuk menerima stimulus. Adanya syaraf sensoris sebagai alat untuk meneruskan stimulus yang diterima reseptor ke pusat susunan syaraf yaitu otak sebagai pusat kesadaran. Sebagai alat untuk mengadakan respon diperlukan syaraf motoris.

3. Perhatian

Untuk menyadari atau untuk mengadakan persepsi diperlukan adanya perhatian, yaitu merupakan langkah pertama sebagai suatu persiapan dalam rangka mengadakan persepsi. Perhatian merupakan pemusatan atau konsentrasi dari seluruh aktivitas individu yang ditujukan kepada sesuatu atau sekumpulan objek.

Selain itu Walgito (2000: 54) mengatakan bahwa factor yang mempengaruhi persepi antara lain adalah factor internal dan factor eksternal. Faktor internal tersebut antara lain kebutuhan psikologis, latar belakang pendidikan, alat indera, syaraf atau pusat susunan syaraf, kepribadian dan pengalaman penerimaan diri serta keaadaan individu pada waktu tertentu. Penelitian ini akan menanyakan mengenai persepsi wisatawan secara umum mengenai Bali di kedua tempat tersebut.

\section{Daerah Wisata Sanur dan Canggu}

\section{Sanur}

Pantai Sanur terletak pada $8^{\circ} 38^{\text {ce }} 00^{\prime \prime}$ dan $08^{\circ} 42^{\circ e} 30^{\prime \prime}$ LS, $115^{\circ} 16^{\prime \prime} 30^{\prime \prime}$ BT.

Luas wilayah kawasan pariwisata pantai Sanur adalah 1.548,27 Ha. Secara administratif, pantai Sanur terletak di bagian kota Denpasar, terletak di sebagian Kecamatan Denpasar Selatan yaitu terdiri di wilayah kelurahan Sanur, wilayah 
Desa Sanur Koja, wilayah Desa Sanur Kauh, serta di Kecamatan Denpasar Timur yaitu wilayah desa Kesiman Petilan dan wilayah Desa Kesiman Kertalangu.Dan untuk menuju ke lokasi tersebut sangat mudah karena sekitar $50 \mathrm{~m}$ dari pantai sudah berdiri berbagai hotel serta jalan yang lebar dan beraspal (Widiyani dan Sukma,tanpa tahun). Aksesibilitas kawasan pariwisata Sanur cukup tinggi, mengingat kawasan tersebut berada antara kawasan pariwisata Kuta dan Nusa Dua serta merupakan akses menuju kawasan pariwisata ke kabupaten Gianyar, Bangli, Klungkung, dan Karangasem. Disamping itu jarak kawasan Sanur dengan pusat pemerintahan Kota Denpasar berjarak sekitar $7 \mathrm{~km}$, dengan fasilitas sarana dan prasarana seperti, transportasi, komunikasi yang sangat mendukung.

Objek Wisata Pantai Sanur merupakan pantai yang bersejarah karena Pantai ini merupakan pantai tempat mendaratnya pasukan kerajaan Belanda ketika Belanda menyerang wilayah Badung pada waktu zaman penjajahan. Sanur berasal dari dua kata, "Saha" dan "Nuhur" yang secara harfiah berarti keinginan/gairah untuk mengunjungi tempat tertentu, dan menurut pendapat dari beberapa pemuka adat menjelaskan bahwa "Saha" dan "Nuhur" berarti memohon untuk datang di suatu tempat. Dari kata tersebut lama kelamaan berubah menjadi Sanur. Dalam kaitannya dengan sejarah Bali, Sanur tercatat sebagai tempat dimana salah satu prasasti Bali yang paling tua ditemukan. Dalam prasasti Belanjong yang berangka tahun 917
M, dapat diperkirakan bahwa pada masa tersebut di daerah Sanur sekarang ini sudah difungsikan sebagai daerah pelabuhan. Pada tahun 1951-1959 mulai nampak titiktitik terang yaitu dengan penunjukan Desa Sanur sebagai desa percobaan oleh Gubernur Provinsi Bali pada tahun 1956. (Widiyani dan Sukma, tanpa tahun).

Warren mengatakan bahwa Sanur merupakan kawasan wisata di Bali sejak tahun 1930-an (Picard, 2006:108). Seorang pelukis Belgia, bernama Adrian-Jean Le Mayeur de Merpres kemudian menetap di daerah Sanur dengan istrinya $\mathrm{Ni}$ Polok dan hingga saat ini namanya diabadikan sebagai nama museum lukisan yang memajang hasil karya Beliau. Hotel yang pertama kali ada di kawasan pantai Sanur adalah Hotel Sindhu Beach yang dibangun pada tahun 1957 kemudian disusul oleh pembangunan Hotel Bali Beach pada tahun 1963 dan beroperasi pada tahun 1966 (Kurniati dan Siagian, 1996). Proyek pengembangan Sanur sebagai kawasan wisata juga berlanjut hingga tahun 1971 disebut sebagai Beach Market yang merupakan program pengembangan dengan menyajikan jasa pelayaran dengan jukung (perahu tradisional), pameran patung-patung, lukisan, pertunjukan tari-tarian dan pengelolaan kafe dan restoran.

Suarka, Sulistyawati dan Sari (2017) menyatakan bahwa karakteristik wisatawan di Sanur yang sebagian besar adalah orang Eropa dan Australia memiliki karakter lanjut usia atau diatas 55 tahun. Sedangkan wisatawan yang berasal dari Jepang 
dan Cina maupun Taiwan memiliki segmen usia remaja sampai dewasa. Aktivitas wisata yang dilaksanakan oleh wisatawan lanjut usia tersebut sebagian besar memilih kegiatan relaksasi ataupun kegiatan yang bersifat pasif (passive leisure), santai serta menambah pengalaman yang berkaitan dengan kegiatan-kegiatan sosial budaya masyarakat Sanur. Selain itu, dari penelitian yang dilakukan oleh Suarka, Sulistyawati dan Sari (2017) juga didapati responden yang berpartisipasi yang berusia lanjut usia sebanding dengan wisatawan yang berusia remaja dan dewasa. Menurut Suardika dalam Utama (2016), wisatawan lanjut usia memiliki karakter yang berpotensi meningkatkan pendapatan Daerah karena memiliki kecenderungan untuk tinggal di suatu daerah wisata lebih lama serta cenderung untuk berbagi pengetahuan dan keterampilan dengan penduduk lokal. Sebagai tambahan mereka juga tinggal tidak mengenal musim dalam mengunjungi suatu tempat wisata.

\section{Canggu}

Desa Canggu termasuk di wilayah Kabupaten Badung, lebih spesifik adalah Kecamatan Kuta Utara. Daerah Canggu letaknya sekitar 20 menit dari Seminyak, sehingga dapat menjadi pilihan bagi wisatawan asing yang masih ingin melihat kehidupan masyarakat Bali dengan areal persawahan masih dapat ditemui dengan lokasi yang masih dapat menjangkau areal turistik Kuta. Daerah Canggu juga terletak sekitar 25 menit ke areal Tabanan apabila ingin melihat destinasi Pura Tanah Lot bagi wisatawan asing yang ingin melihat kebudayaan Bali. Jumlah penduduk Desa Canggu secara keseluruhan mencapai 6,629 orang dengan kepadatan penduduk sebesar 1,265 (jiwa/km2). Kepadatan penduduk tersebut meningkat dari 1,028 pda tahun 2016 menjadi 1,265 pada tahun 2017 (Desa Canggu, 2018). Ditulis oleh Surya (2018) pada Denpostnews.com, bahwa Canggu yang sekarang tidak seperti Canggu yang dulu. Seperti yang dikatakan oleh Tyson Wijaya Kusuma, yang dikutip oleh Denpostnews, bahwa Kegiatan pariwisata di Canggu dimulai sejak tahun 2000 terutama dari pseona ombak di Canggu.

Hampir 70 persen masyarakat di Canggu mengalihkan mata pencaharian ke sektor pariwisata dan pembangunan Canggu terus berkembang hingga saat ini Berdasarkan data dari kantor desa setempat, sebanyak 479 akomodasi pariwisata seperti hotel, restoran, villa, homestay, bar dan lainnya tercatat pada tahun 2017. Meskipun alih fungsi lahan terjadi di Canggu, akan tetapi hanya sebagian kecil masyarakat yang menjual tanahnya ke investor. Saat ini lahan pertanian dan subak masih dapat dijumpai di beberapa Banjar dan kegiatan untuk melihat lahan sawah tersebut diminato oleh para tamu. Dilansir dari salah satu tulisan Anonim di Surfer.com (2010), daerah Canggu juga banyak dipilih oleh ekspatriat yang berasal dari Eropa untuk tinggal sejak enam tahun yang lalu (sekitar tahun 2004).

\section{METODE PENELITIAN}

Lokasi penelitian ini dilaksanakan di Desa Sanur di daerah Denpasar dan di Desa Canggu di daerah Kuta Utara, Bali. Penelitian dilaksanakan pada 
tahun ini antara bulan April-Juni 2018. Teknik sampling yang digunakan adalah random sampling, yakni sampel merupakan wisatawan mancanegara yang berada di kawasan wisata tersebut. Sumber data yang digunakan dalam penelitian ini adalah sumber data primer dan sumber data sekunder. Sumber data primernya menggunakan kuesioner yang disebarkan kepada total 33 wisatawan mancanegara di Sanur dan 38 wisatawan di daerah Canggu. Sedangkan sumber data sekunder merupakan data dari literatur yang telah ada dan digunakan dalam penulisan penelitian ini. Adapun data yang digunakan juga data kualitatif maupun data kuantitatif. Data kualitatif adalah data yang berupa pemikiran, opini, maupun sumber yang lain, sedangkan data kuantitatif adalah data yang berupa angkaangka. Teknik penelitian yang digunakan adalah kuesioner, dan studi literatur.

Pendekatan yang digunakan dalam penelitian ini adalah deskriptif kualitatif, yaitu pengukuran yang cermat terhadap fenomena social tertentu. Oleh karena penelitian ini ditujukan kepada analisis masalah, maka metode ini tidak hanya terbatas pada penghimpunan dan menyusun data dari berbagai fakta yang ada, akan tetapi melihat analisa dan interpretasi tentang arti data tersebut. Penelitian ini dilakukan dengan cara meneliti perkembangan lingkungan alam dan lingkungan social serta perilaku social yang bersifat eksplanatoris (explanatory research) yaitu, penelitian yang memberikan informasi secara rinci dan mendalam mengenai praktik kegiatan kepariwisataan yang dilakukan oleh turis asing di Bali. Sedangkan untuk data sekunder diperoleh dengan studi literatur yang terkait dengan subjek dan objek penelitian. Data primer yang dan sekunder kemudian akan dianalisis dengan menggunakan teknik analisis deskriptif kualitatif yang selanjutnya akan mendeskripsikan, menguraikan, menjelaskan dan menjabarkan secara jelas dan sistematis.

\section{HASIL DAN PEMBAHASAN}

Berdasarkan penelitian yang dilakukan dengan total kepada 81 wisatawan yang berada di Sanur dan Canggu, maka peneliti mendapatkan beberapa hal mengenai karakteristik wisatawan sesuai dengan jenis trip desciptor maupun tourist descriptor nya. Peneliti mendapatkan 33 wisatawan mancanegara di daerah Sanur dan 48 wisatawan mancanegara di daerah Canggu. Perlu diketahui bahwa dari segi jumlah, maka Canggu akan terlihat lebih banyak wisatawannya dibandingkan dengan Sanur dari penelitian ini. Sehingga peneliti akan menganalisis dari poin yang relatif signifikan. Berikut adalah tabel hasil karakteristik wisatawan mancanegara di Sanur dan Canggu.

Tabel 1. Karakteristik Wisatawan Mancanegara di Sanur dan Canggu Berdasarkan Tourist Descriptor

\begin{tabular}{|l|l|l|l|}
\hline $\begin{array}{l}\mathrm{N} \\
\mathrm{O}\end{array}$ & $\begin{array}{l}\text { Tipe } \\
\text { Diferensi } \\
\text { asi }\end{array}$ & Sanur & Canggu \\
\hline 1 & Gender & $\mathrm{P}=15$ & $\mathrm{P}=29$ \\
& & $\mathrm{~L}=18$ & $\mathrm{~L}=19$ \\
& & Total $=33$ & Total =48 \\
\hline 2 & Rentang & $18-24=8$ & $18-24=15$ \\
& Usia & $25-31=8$ & $25-31=13$ \\
& & $32-38=6$ & $32-38=7$ \\
& & $39-45=4$ & $39-45=9$ \\
& & $>46=6$ & $>46=4$ \\
\hline
\end{tabular}




\begin{tabular}{|c|c|c|c|}
\hline 3 & $\begin{array}{l}\text { Tingkat } \\
\text { Pendidik } \\
\text { an }\end{array}$ & $\begin{array}{l}\text { SMA }=6 \\
\text { College\&Dip } \\
\text { loma }=12 \\
\text { Universitas } \\
=8 \\
\text { Master }=4 \\
\text { Post- } \\
\text { Graduate }=2\end{array}$ & $\begin{array}{l}\text { SMA }=7 \\
\text { College\&Dip } \\
\text { loma }=11 \\
\text { Universitas } \\
=17 \\
\text { Master }=7 \\
\text { Post- } \\
\text { Graduate = } \\
6\end{array}$ \\
\hline 4 & $\begin{array}{l}\text { Informasi } \\
\text { tentang } \\
\text { Bali dari : }\end{array}$ & $\begin{array}{l}\text { Teman }=16 \\
\text { Agen travel } \\
=4 \\
\mathrm{TV}=1 \\
\text { Iklan }=0 \\
\text { Internet }=7 \\
\text { Keluarga }=5\end{array}$ & $\begin{array}{l}\text { Teman }=33 \\
\text { Agen travel } \\
=3 \\
\text { TV }=3 \\
\text { Iklan }=3 \\
\text { Internet }=17 \\
\text { Keluarga }=6\end{array}$ \\
\hline 5 & $\begin{array}{l}\text { Negara } \\
\text { Asal } \\
\text { berdasar } \\
\text { kan } \\
\text { benua }\end{array}$ & $\begin{array}{l}\text { Eropa }=15 \\
\text { Asia }=5 \\
\text { Amerika }=3 \\
\text { Australia = } 8 \\
\text { Afrika }=2\end{array}$ & $\begin{array}{l}\text { Eropa }=28 \\
\text { Asia }=4 \\
\text { Amerika }=4 \\
\text { Australia }=9 \\
\text { Afrika }=1\end{array}$ \\
\hline 6 & $\begin{array}{l}\text { Pekerjaa } \\
\mathrm{n}\end{array}$ & $\begin{array}{l}\text { Pelajar }=4 \\
\text { Entrepreneu } \\
r=1 \\
\text { Creative }=3 \\
\text { Nurse }=1 \\
\text { Engineer }=1 \\
\text { Marketing = } \\
2 \\
\text { Teacher }=4 \\
\text { Parent }=2 \\
\text { Pensiunan = } \\
2 \\
\text { HRD }=1 \\
\text { Sport }=1\end{array}$ & $\begin{array}{l}\text { Pelajar }=10 \\
\text { Entrepreneu } \\
r=1 \\
\text { Creative }=7 \\
\text { Doctor }=1 \\
\text { Engineer }=3 \\
\text { Marketing }= \\
4 \\
\text { Teacher }=3 \\
\text { Parent }=1 \\
\text { Accountant } \\
=4 \\
\text { Sport }=3 \\
\text { Lawyer }=1\end{array}$ \\
\hline 7 & $\begin{array}{l}\text { Berapa } \\
\text { kali } \\
\text { sudah } \\
\text { mengunj } \\
\text { ungi Bali? }\end{array}$ & $\begin{array}{l}\text { Sekali }=15 \\
\text { Dua kali }=6 \\
\text { Tiga kali }=2 \\
\text { >tiga kali }= \\
10\end{array}$ & $\begin{array}{l}\text { Sekali }=21 \\
\text { Dua kali }=11 \\
\text { Tiga kali }=5 \\
\text { >tiga kali }= \\
11\end{array}$ \\
\hline
\end{tabular}

Sumber: Data Diolah, 2018.

Dapat dilihat dari segi demografis, perbedaan wisatawan di Sanur dan di Canggu adalah dari segi usia. Usia wisatawan mancanegara di Sanur yang dikategori lebih dari 46 tahun, berjumlah 6 sedangkan di Canggu hanya berjumlah 4 orang dari total 48 wisatawan di Canggu. Hal ini menandakan bahwa wisatawan mancanegara yang berusia lanjut masih memilih Sanur untuk berwisata. Dari segi lama tinggal,
Sanur juga menjadi pilihan wisatawan tersebut untuk tinggal lebih lama, karena 4 orang wisatawan memilih tinggal di Sanur untuk sekitar 3 bulan. Jenis wisatawan mancanegara dari segi usia di Canggu lebih dominan yang berusia aktif dan relatif muda, yakni sekitar 18-24 tahun sebanyak 15 orang, dan 25-31 tahun sebanyak 13 orang. Namun dapat juga kita lihat dari tabel di atas, bahwa di Sanur juga wisatawan mancanegara yang berusia sekitar 18-31 tahun tersebut paling banyak dibandingkan dengan jumlah wisatawan yang berusia lanjut. Hal ini dapat mengindikasikan bahwa secara umum, karakteristik wisatawan mancanegara yang datang ke Bali dari segi usia banyak yang berusia relatif muda dan aktif.

Tabel 2. Karakteristik Wisatawan Mancanegara di Sanur dan Canggu Berdasarkan Trip Descriptor

\begin{tabular}{|c|c|c|c|}
\hline $\begin{array}{l}\mathrm{N} \\
\mathrm{O}\end{array}$ & $\begin{array}{l}\text { Tipe } \\
\text { Diferensiasi }\end{array}$ & Sanur & Canggu \\
\hline 1 & $\begin{array}{l}\text { Dengan } \\
\text { siapa } \\
\text { bepergian } \\
\text { ke } \\
\text { Sanur/Cang } \\
\text { gu }\end{array}$ & $\begin{array}{l}\text { Sendiri = } 16 \\
\text { Dengan } \\
\text { teman = 4 } \\
\text { Berkelomp } \\
\text { ok = } 1 \\
\text { Dengan } \\
\text { pasangan = } \\
5 \\
\text { Dengan } \\
\text { keluarga = } \\
7\end{array}$ & $\begin{array}{l}\text { Sendiri = } 13 \\
\text { Dengan } \\
\text { teman = } 14 \\
\text { Berkelomp } \\
\text { ok = 3 } \\
\text { Dengan } \\
\text { pasangan = } \\
17 \\
\text { Dengan } \\
\text { keluarga = } \\
1\end{array}$ \\
\hline 2 & $\begin{array}{l}\text { Tipe } \\
\text { Akomodasi }\end{array}$ & $\begin{array}{l}\text { Hotel = } 23 \\
\text { Resort = } 3 \\
\text { Homestay } \\
=5 \\
\text { Villa = } 3 \\
\text { Bungalow } \\
=0 \\
\text { Hostel = } 0\end{array}$ & $\begin{array}{l}\text { Hotel }=2 \\
\text { Resort }=5 \\
\text { Homestay } \\
=8 \\
\text { Villa }=27 \\
\text { Bungalow } \\
=2 \\
\text { Hostel }=3\end{array}$ \\
\hline 3 & $\begin{array}{l}\text { Moda } \\
\text { Transporta } \\
\text { si selama } \\
\text { perjalanan }\end{array}$ & $\begin{array}{l}\text { Transporta } \\
\text { si public = } 2 \\
\text { Sepeda } \\
\text { motor/skut } \\
\text { er }=14 \\
\text { Sepeda = } 0 \\
\text { Taxi }=13\end{array}$ & $\begin{array}{l}\text { Transporta } \\
\text { si public = } 3 \\
\text { Sepeda } \\
\text { motor/skut } \\
\text { er = } 31 \\
\text { Sepeda = } 2 \\
\text { Taxi = } 3\end{array}$ \\
\hline
\end{tabular}




\begin{tabular}{|c|c|c|c|}
\hline & & Mobil = 1 & Mobil $=6$ \\
\hline 4 & $\begin{array}{l}\text { Lama } \\
\text { tinggal atau } \\
\text { Length of } \\
\text { Stay (LoS) }\end{array}$ & $\begin{array}{l}\text { Selamanya } \\
= \\
1-10 \text { hari }= \\
20 \\
11-20 \text { hari = } \\
3 \\
21-30 \text { hari } \\
=2 \\
31-40 \text { hari } \\
=- \\
41-50 \text { hari } \\
=- \\
2 \text { bulan }=- \\
3 \text { bulan }=4 \\
4 \text { bulan }=1 \\
6 \text { bulan }=- \\
2 \text { tahun }=-\end{array}$ & $\begin{array}{l}\text { Selamanya } \\
=1 \\
1-10 \text { hari }= \\
11 \\
11-20 \text { hari }= \\
8 \\
21-30 \text { hari } \\
=10 \\
31-40 \text { hari } \\
=1 \\
41-50 \text { hari } \\
=2 \\
2 \text { bulan }=3 \\
3 \text { bulan }=2 \\
6 \text { bulan }=1 \\
2 \text { tahun }=1\end{array}$ \\
\hline 6 & $\begin{array}{l}\text { Tipe } \\
\text { makanan }\end{array}$ & $\begin{array}{l}\text { Western } \\
=16 \\
\text { Local = } 20 \\
\text { Vegetarian } \\
=0\end{array}$ & $\begin{array}{l}\text { Western = } \\
10 \\
\text { Local = } 38 \\
\text { Vegetarian } \\
=1\end{array}$ \\
\hline 7 & $\begin{array}{l}\text { Pengeluara } \\
\text { n sehari } \\
\text { sekitar }\end{array}$ & $\begin{array}{l}\text { US\$10 }=0 \\
\text { US\$20 }=5 \\
\text { US\$30 }=14 \\
\text { US\$ } 40=7 \\
\text { US\$ } 50=0 \\
>U S \$ 50=7\end{array}$ & $\begin{array}{l}\text { US\$ } 10=3 \\
\text { US\$ } 20=13 \\
\text { US\$ } 30=15 \\
\text { US\$ } 40=7 \\
\text { US\$ 50=5 } \\
>\text { US\$ } 50= \\
4\end{array}$ \\
\hline
\end{tabular}

Sumber: Data diolah pribadi, 2018.

Dari segi tingkat pendidikan, wisatawan yang datang ke Sanur dengan tingkat SMA ternyata masih relatif banyak dan hampir sebanding dengan wisatawan yang datang ke Canggu. Menariknya, bahwa wisatawan di Sanur dan Canggu banyak yang sudah berkali-kali ke Sanur maupun Canggu. Selain itu didukung oleh data bahwa wisatawan dengan profesi atau berstatus sebagai pelajar yang menjadi data terbanyak dari daerah Sanur dan Canggu, terutama Canggu. Informasi yang didapatkan mengenai
Bali sebagian besar berasal dari teman dan internet bagi wisatawan tersebut.

Hal lain yang menarik ditemui adalah dari segi lama tinggal, karena wisatawan di Canggu ada yang memilih untuk tinggal selamanya di Bali, dan juga 2 tahun serta beragam pilihan lamanya tinggal. Sedangkan di Sanur sebagian besar wisatawan memilih untuk tinggal sekitar 1-10 hari. Selain itu, Sanur juga dipilih menjadi tempat pergi bagi wisatawan yang membawa keluarga jumlahnya lebih besar dibandingkan dengan wisatawan di Canggu. Akan tetapi wisatawan di Sanur yang datang sendiri jumlahnya paling banyak dibandingkan dengan wisatawan yang datang dengan pasangan maupun dengan keluarga. Sedangkan di Canggu paling banyak wisatawan datang dengan pasangannya.

Perbandingan yang unik yang lain adalah di bagian akomodasi, wisatawan di Sanur sebagian besar memilih tinggal di Hotel dan tidak ada wisatawan yang memilih tinggal di Hostel. Sedangkan di Canggu banyak wisatawan yang memilih tinggal di villa dan ada yang memilih hostel. Dari hasil tersebut juga didapati bahwa tamu dari Jerman, menjadi jumlah wisatawan terbanyak namun secara umum dari benua Eropa menjadi paling banyak dari data ini kemudian baru disusul oleh Australia bagi wisatawan yang berkunjung ke Canggu. Sedangkan untuk di Sanur, wisatawan mancanegara dari Australia merupakan jumlah terbanyak, meskipun apabila digabungkan 
wisatawan asal benua Eropa tetap lebih banyak.

Mengenai persepsi wisatawan di Sanur maupun di Canggu, secara umum hasil data yang didapatkan mengenai persepsi wisatawan tentang kebersihan, keamanan, dan kepuasan relatif sama. Seperti pada pernyataan bahwa sebagian besar wisatawan menginginkan untuk berkunjung kembali ke Bali. Hanya 4 wisatawan saja yang mengatakan tidak dan 1 wisatawan yang ragu-ragu apabila berkunjung. Sebagian besar wisatawan di Sanur dan Canggu juga menganggap bahwa kebersihan di Sanur maupun di Canggu netral (memilih angka 3 dari rentang penilaian 1 sampai dengan 5). Untuk persepsi wisatawan mengenai keamanan agak unik, karena sebagian besar wisatawan memilih menyatakan Bali aman dengan sebagian besar memilih nomor 4 dan nomor 5. Sebagian besar wisatawan juga memilih puas terhadap pengalamannya selama di Bali. Hal ini juga sesuai dengan jumlah wisatawan yang menyatakan ingin kembali lagi ke Bali. Atraksi pantai memang menjadi dominan bagi aktivitas wisatawan mancanegara di kedua tempat tersebut. Akan tetapi hal menarik yang dapat diambil adalah wisatawan di Sanur lebih banyak yang ingin melihat kebudayaan (10 wisatawan) dibandingkan dengan di Canggu (8 wisatawan).

\section{KESIMPULAN}

Karakteristik

wisatawan

mancanegara yang datang ke Bali saat ini dari segi demografis adalah wisatawan yang berusia aktif dan relatif muda dengan atraksi pariwisata yang dicari sebagian besar oleh wisatawan tersebut adalah pantai. Pergesaran karakteristik wisatawan asing tersebut meskipun terjadi secara umum, akan tetapi tetap memberikan perbedaan bagi daerah wisata di Bali seperti Sanur dan Canggu yang memiliki kekhasan tersendiri bagi wisatawan mancanegara dari segi tourist descriptor maupun trip descriptor. Dari segi persepsi wisatawan mengenai daerah wisata tersebut, mereka sebagian besar melihat kebersihan menjadi sedikit permasalahan meskipun kepuasan sudah mereka dapatkan dari perjalanan yang mereka lakukan.

\section{Daftar Pustaka}

Anonim. 2010. [https://www.surfer.com/feature s/bali_dispatch_canggu/]. Online. Diakses pada tanggal 1 Oktober 2018.

Desa Canggu. 2018. Jumlah Penduduk. Online. [http://desacanggu.badungkab.g o.id/page/1179/Jumlah-

Penduduk.html]. Diakses pada tanggal 1 Oktober 2018.

Ardhana, Sudarsono. 1963. PokokPokok Ilmu Jiwa Umum. Surabaya: Usaha Nasional.

Arifin, M. 2010. Kepemimpinan dan Motivasi Kerja. Yogyakarta: Teras.

Badan Pusat Statistik. 2018. Jumlah Wisatawan Asing ke Indonesia dan Bali, 1969-2017. Online. [https://bali.bps.go.id/statictable/ 2018/02/09/28/jumlah-wisatawanasing-ke-bali-dan-indonesia-19692017.html]. Diakses pada tanggal 1 Oktober 2018.

Bank DUnia. 2003. Bali Setelah Tragedi. 
Francillon, Gérard. 1979. Balil: Tourism, Culture, Environment, Universitas Udayana-UNESCO.

Indrawarti, Yayu. 2010. Persepsi Wisatawan Lanjut Usia pada Fasilitas Akomodasi dan Aktivitas Pariwisata Bernuansa Seni Budaya di Desa Sanur. Jurnal ISIDenpasar.

Fandeli, Chafid dan Mukhlison. 2000. Pengusahaan Ekowisata. Yogyakarta: Fakultas Kehutanan UGM dan BKSDA Yogykarta.

Gibson, et al. 1995. Organisasi: Perilaku, Struktur, Proses. Jilid 1. Jakarta: Erlangga.

Gregorius. 2008. If Only Bali Had Listened to Its French Consultants.

http://www.balidiscovery.com/messa ges/printmessage.asp?ld=4223, retrieved in 25 January 2013.

Kurniati, Ni Made Taganing dan Siagian, Yeni D.S. 1996. Perkembangan Pariwisata dan Perubahasan Sosial di Sanur Kaja, Kotamadya Denpasar, Propinsi Bali dengan Tinjauan Psikologi. Buletin Penalaran Mahasiswa UGM. Vol. 2.No. 2. Agustus 1996. P. (36-39).

Malbos, Frédérique. 2010. Bali. Casa Editrice Bonechi, Italy.

Pemerintah Kota Denpasar. $<$ http://denpasarkota.go.id/instansi/?cid $==1 j M \& \mathrm{~s}=$ =menu\&id $=345,>$ downloaded in 22 October 2012. 21.19

Rivai, Veithzal. 2002. Kepemimpinan dan Perilaku Organisasi. Jakarta: PT. Raja Grafindo Persada.

Robin, Stephen P. 2003. Perilaku Organisasi. Jakarta: PT. Indeks.

Suarka, Fanny Maharani., Sulistyawati, Agung Sri., dan Sari, $\mathrm{Ni}$ Putu. 2017. Pengembangan Leisure and Recreation For Later Life (Wisatawan Lanjut Usia) di
Kawasan Wisata Sanur-Bali. Jurnal Analisis Pariwisata. Vol. 17. No. 2.

Seaton, AV \& Bennet. 1996. The marketing of Tourism Products: Concepts, Issues and Cases. London International Thomson Business Press.

Sunaryo, T. 2004. Psikologi untuk Keperawatan. Jakarta: EGC.

Sugihartono. 2007. Psikologi Pendidikan. Yogyakarta: UNY Press.

Surya. 2018. Pariwisata Canggu Kian Menggeliat.

[http://denpostnews.com/2018/0 1/30/pariwisata-canggu-kianmenggeliat/]. Diakses pada tanggal 1 Oktober 2018.

Vickers, Adrian. 2012. Bali: A Paradise Created. 2nd Ed. Tuttle Publishing, Singapore.

The World Travel and Tourism Council-WTTC. 2015. Yearbook of Tourism Statistics. WTTC Database, Madrid.

Utama, I Gusti Rai. 2016. Keunikan Budaya dan Keindahan Alam sebagai Citra Destinasi Bali Menurut Wisawatawan Australia Lanjut Usia. Jurnal Kajian Bali. Volume 06, Nomor 1.

Waidi. 2006. The Art of Reengineering Your Mind for Success. Jakarta: Gramedia.

Walgito, Bimo. 2004. Pengantar Psikologi Umum. Jakarta: Andi.

Widiyani, Desak Made Sukma. Tanpa Tahun. Perkembangan Daerah Pariwisata Sanur (Dilihat dari Teori Lokasi Growth Pole). 